\title{
On the calciumcarbonate content of young marine sediments
}

\author{
B. VERHOEVEN \\ Zuiderzeepolders Development and Colonisation Authority, Soil Research \\ Division, Kampen
}

\section{Summary}

Samples have been analysed from freshly deposited marine sediments along the continental coast of the Northsea and from the material suspended in the seawater of the Dutch Wadden area (see MAP).

In the coarser sediments the $\mathrm{CaCO}_{3}$-content increases with increasing clay content, in the more clayey sediments the $\mathrm{CaCO}_{3}$-content often is next to constant. Within one region the $\mathrm{CaCO}_{3}$ content of each soil fraction is nearly constant. Below 75 micron the $\mathrm{CaCO}_{3}$-content of the fractions increases with decreasing particle size. The clay fraction, however, is relatively poor in $\mathrm{CaCO}_{3}$. This size distribution of the $\mathrm{CaCO}_{3}$ will be caused mainly by disintegration during the transport.

In deposits with comparable clay content the $\mathrm{CaCO}_{3}$-content decreases from south to north. In the brackish region of river mouths it decreases in inward directon. However, the relations between the $\mathrm{CaCO}_{3}$-contents of the various fractions are rather similar all along the coast in question. These geographical differences in $\mathrm{CaCO}_{3}$-content may be governed mainly by the $\mathrm{CaCO}_{3}-$ contents of the material from which the sediments originate. Locally other factors play a part too.

The $\mathrm{CaCO}_{3}$ consists chiefly of more or less recognisable material of organic origin: crushed shells, Foraminifera, Ostracoda, spines of Echinodermata etc. In the finer fractions some crystals have been found too, rhomboeders or fine needles.

Generally, about $5-30 \%$ of the total carbonates is bound to magnesium.

\section{Introduction}

The $\mathrm{CaCO}_{3}$-content of newly deposited marine sediments is rather variable. In view of this variability, many samples of sediments have been analysed on $\mathrm{CaCO}_{3}$-content in the laboratories of the Zuiderzeepolders Development and Colonisation Authority.

Since, in 1956, the determination of $\mathrm{CaCO}_{3}$ became part of the determination of the clay content (by pipet analysis), the number of available $\mathrm{CaCO}_{3}$-figures increased considerably.

With respect to the Dutch coast thousands of $\mathrm{CaCO}_{3}$-figures were available (not included those data which have been gathered by other institutes); moreover about 60 samples were taken along the Danish coast (southern Jutland), the German and Belgian coast and along the French coast (Départements Nord, Pas de Calais and Somme). Nearly 240 samples from the English Northsea coast proved to be of some use and 53 samples from the bottom of the Northsea gave information on the $\mathrm{CaCO}_{3}$-content of sediments farther from the coast (see MAP).

It has to be stated that only newly deposited sediments may be taken in account.

Received for publication 9th November, 1961. 
As soon as soil development starts, the relations mentioned above are disturbed, the rate of decrease of $\mathrm{CaCO}_{3}$-content caused by soil development being very unequal (BEEFTINK, 1962) and depending on conditions of soil formation (FIG. 1).

In comparing $\mathrm{CaCO}_{3}$-contents of fresh marine deposits, it, moreover, has to be kept in mind that, generally, the $\mathrm{CaCO}_{3}$-content of not full-marine estuarine deposits is relatively low.

FIg. 1. Relation between $\mathrm{CaCO}_{3}$-content and clay content (both in $\mathrm{g}$ per $100 \mathrm{~g}$ dry matter) in young sediments in the Grevelingen area

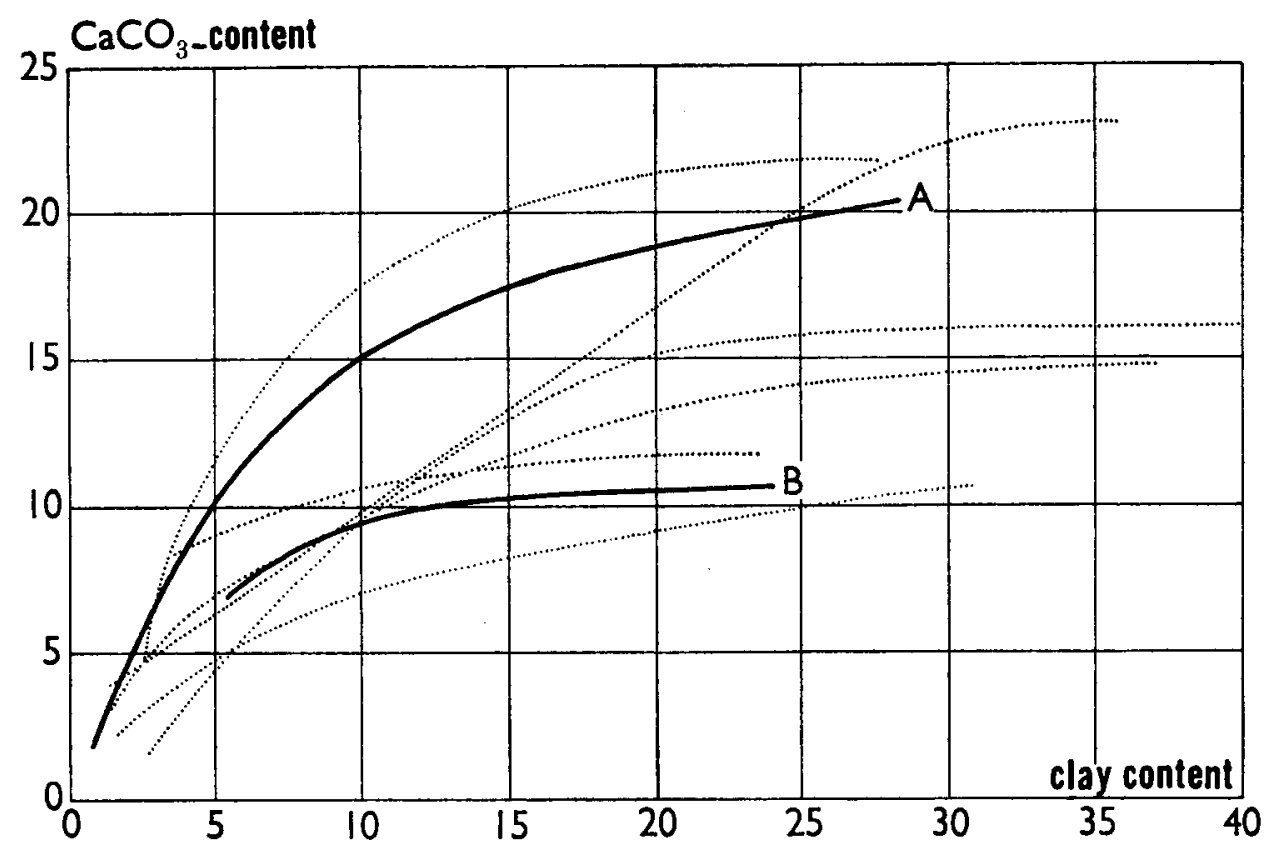
A bare sediments
B sediments covered with Spartina

\section{Methods of analysis}

\subsection{Clay and silt}

$20 \mathrm{~g}$ of soil (sandy soils $40 \mathrm{~g}$ ) are treated with $\mathrm{H}_{2} \mathrm{O}_{2} 30 \%$ and $\mathrm{HCl} 0,2 \mathrm{n}$. After decanting, the soil is peptised with $\mathrm{Na}_{4} \mathrm{P}_{2} \mathrm{O}_{7}$ and clay- (and silt)content is determined by pipetting samples of the suspensions after a fixed time and on a predetermined depth.

After 1956 the quantity of $\mathrm{H}_{2} \mathrm{O}_{2}$ used has been standardized, the quantity of $\mathrm{HCl}$ is in accordance with the $\mathrm{CaCO}_{3}$-content of the sample and $\mathrm{Na}_{4} \mathrm{P}_{2} \mathrm{O}_{7}$ replaced the $\mathrm{Na}_{2} \mathrm{CO}_{3}$ used formerly. These changes caused slightly higher (HoOGHOUDT, 1945; HoFSTEE, 1955) and decidedly more accurate figures than the former method.

\section{2. $\mathrm{CaCO}_{3}$}

$1-3 \mathrm{~g}$ of soil are shaken with $\pm 20 \mathrm{ml} \mathrm{HCl}(8$ à $10 \%)$ and the produced $\mathrm{CO}_{2}$ 
is measured volumetrically. Influence of temperature and atmospheric pressure is controlled by using a standard and a blank (for detailed description see HoFSTEE, 1957).

\section{3.}

In some samples it has been tried to make a division between $\mathrm{CaCO}_{3}$ and $\mathrm{MgCO}_{3}$. It was supposed (BruIN, 1938) that both $\mathrm{CaCO}_{3}$ and $\mathrm{MgCO}_{3}$ solve in $\mathrm{HCl}$ and that only $\mathrm{CaCO}_{3}$ solves in $\mathrm{H}_{4} \mathrm{C}_{2} \mathrm{O}_{2}$. A second method was used in which $\mathrm{MgCO}_{3}$-content was approached by diminishing the $\mathrm{Mg}$ soluble in $8 \% \mathrm{HCl}$ by the exchangeable $\mathrm{Mg}$. Agreement between the two methods was reasonable (BEverwiJk, 1958).

A third method, described by SkinNer a.o. (1959), has been introduced later. This is also a gasiometrical one, in which the rate of reaction between carbonates and $\mathrm{HCl}$ is taken in account. The $\mathrm{CO}_{2}$ evolved is measured with intervals of 10 seconds and the reaction with $\mathrm{CaCO}_{3}$ is assumed to be completed within one minute. The remaining evolution of $\mathrm{CO}_{2}$ is due to dolomite. Some agreement has been found between this method and the two mentioned before.

\section{4 .}

The required soil fractions were obtained by peptising field moist soil with diluted $\mathrm{NH}_{4} \mathrm{OH}$ and siphoning off (in due time) the related fraction. In this way first the $0-2$ micron particles were collected and later $2-8$ micron and $8-16$ micron. The fractions $>16$ micron were fractionated by sieving over $35,50,75$ and 1400 micron sieves.

Suspensions obtained were dried and grinded carefully in a mortar. These fractions, in particular the finer, also contain all other compounds solved in diluted $\mathrm{NH}_{4} \mathrm{OH}$ ( $\mathrm{NaCl}$, humates, silicates). The amount of solved compounds was determined by treating the fractions with $\mathrm{H}_{2} \mathrm{O}_{2}$ and $\mathrm{HCl}$ and filtering under suction. The residue on the filter was weighed (this was the respective fraction without $\mathrm{CaCO}_{3}$, organic matter and a great part of the solved compounds). In some samples, moreover, organic matter content of the fractions has been determined separately. There was a good agreement between the $\mathrm{CaCO}_{3}$-content of the soil determined directly and the $\mathrm{CaCO}_{3}$-content calculated, using the $\mathrm{CaCO}_{3}$-contents of the fractions.

\section{5 .}

In order to study the decalcification of the deposits during sedimentation, a thin layer of sediment was leached in a Buchner funnel. The salinity of the leaching liquid varied, the microbial nutrition status was varied by addition of flour of lucerne and the degree of aeration was influenced by the technique (in particular the speed) of leaching.

\section{Results}

3.1.

Figures 1, 2, 3 and 4 show that, generally, the $\mathrm{CaCO}_{3}$-content of young marine sediments increases with increasing clay content until a certain level and that at higher clay contents, $\mathrm{CaCO}_{3}$-content is fairly constant or even diminishing slightly with increasing clay content. This fact has been stated too by TrILling (1928), MaschHAUPT (1933, 1948), ZUUR (1936), Dechering (1942) and Wiggers (1955).

In order to get more information on the background of the relation shown in this 
FIG. 2. Relation between $\mathrm{CaCO}_{3}$-content and clay content (both in $\mathrm{g}$ per $100 \mathrm{~g}$ dry matter) in recent Zuiderzee-sediments

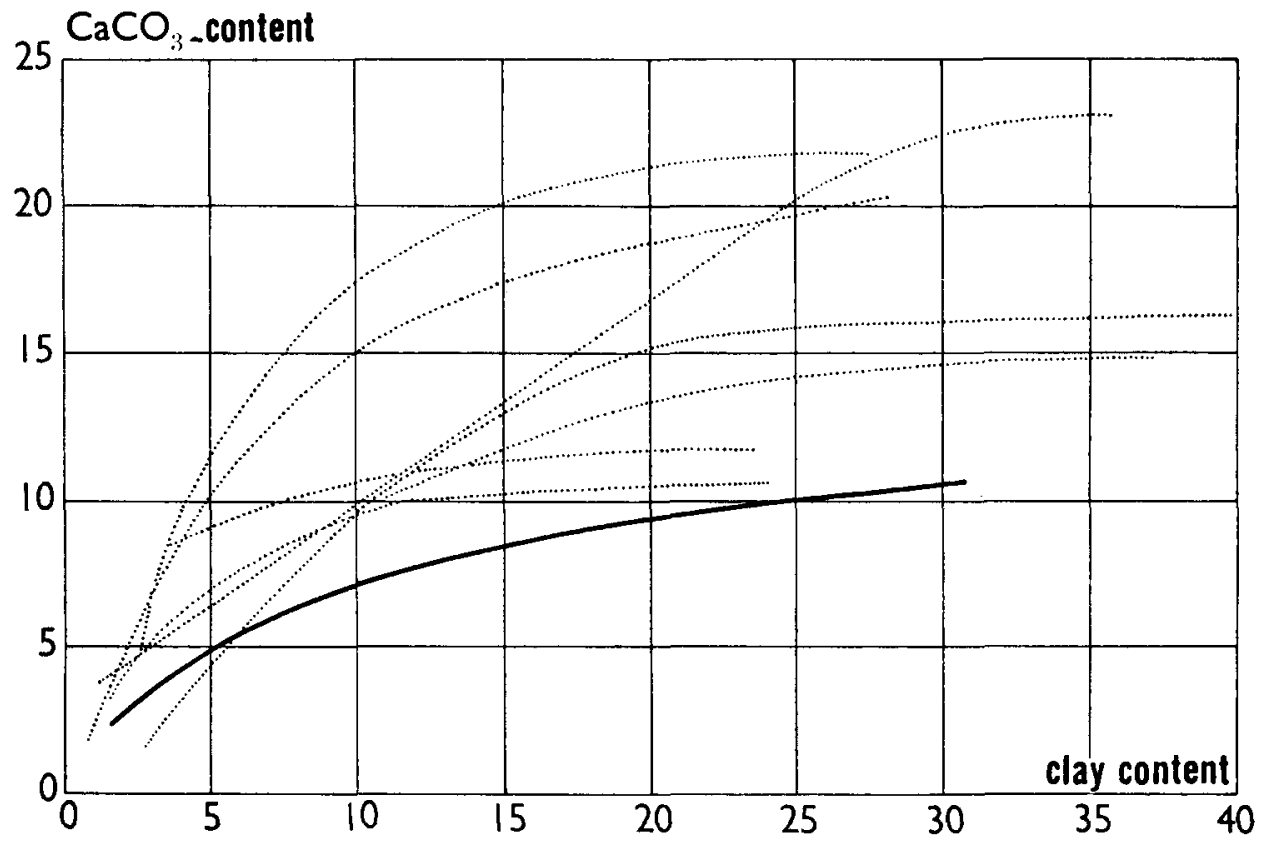

figure, nearly 30 samples have been fractionated and the $\mathrm{CaCO}_{3}$-content of each fraction has been determined.

In all full-marine sediments the fractions $2-8$ and $8-16$ micron show the highest $\mathrm{CaCO}_{3}$-contents, the coarser fractions $(16-35,35-50$ and $50-75$ micron) have a lower $\mathrm{CaCO}_{3}$-content and in all sediments the clay fraction proves to be relatively poor in $\mathrm{CaCO}_{3}$ (TABle 1) (See: Bruin en TEN Have, 1935).

TABle 1. Relative $\mathrm{CaCO}_{3}$-percentages in fractions of marine sediments. The highest $\mathrm{CaCO}_{3}$-content is indicated as $100 \%$

\begin{tabular}{ccccc}
\hline \multirow{2}{*}{$\begin{array}{c}\text { Fraction } \\
\text { in micron }\end{array}$} & \multicolumn{4}{c}{ Relative $\mathrm{CaCO}_{\mathbf{3}}$-percentages } \\
\cline { 2 - 5 } $0-2$ & France & Zuidsloe & Waddensea & Denmark \\
$2-8$ & 38 & 25 & 14 & 12 \\
$8-16$ & 100 & 100 & 100 & 100 \\
$16-35$ & 96 & 83 & 97 & 93 \\
$35-50$ & 81 & 61 & 89 & 71 \\
$50-75$ & 73 & 57 & 71 & 53 \\
Clay content & 68 & 56 & 60 & 48 \\
Total CaCO & 19,0 & 39,5 & 46,3 & 6,9 \\
\hline
\end{tabular}

\section{Note}

This table is not quite correct. It should have been better to determine the $\mathrm{CaCO}_{3}$-percentage of the various fractions based on mineral matter only. However, sufficient data (a.o. organic-matter content) were not available for all fractions. Pertinent controls showed that the figures for $\mathrm{CaCO}_{3}{ }^{-}$ percentages on a mineral matter base do not differ substantially from those in the table. 
In view of this point it should be more logical to plot the $\mathrm{CaCO}_{3}$-content against the silt fraction (2-16 micron) than against the clay fraction.

Moreover it goes from the data obtained that within one region the $\mathrm{CaCO}_{3}$-content of at least the finer fractions is reasonably constant (and independent of the abundance of the particular fraction in the sample) (TABLE 2). This too has been found earlier by ZuUR (1936).

TABLE 2. $\mathrm{CaCO}_{3}$-percentages in fractions of marine Zuiderzee-deposits

\begin{tabular}{|c|c|c|c|c|c|c|c|c|}
\hline $\begin{array}{l}\text { No of } \\
\text { sample }\end{array}$ & $\begin{array}{c}\text { Total } \\
\mathrm{CaCO}_{3}\end{array}$ & $\begin{array}{l}\text { Fraction in } \\
\text { micron }\end{array}$ & $0-2$ & $2-8$ & $8-16$ & $16-35$ & $35-50$ & $50-75$ \\
\hline 13179 & 10,1 & $\begin{array}{l}\% \text { fraction } \\
\% \mathrm{CaCO}_{3} \\
\text { per fraction }\end{array}$ & $\begin{array}{r}22,8 \\
1,4\end{array}$ & $\begin{array}{r}9,7 \\
17,2\end{array}$ & $\begin{array}{r}7,4 \\
19,9\end{array}$ & $\begin{array}{l}16,0 \\
12,2\end{array}$ & $\begin{array}{l}6,4 \\
8,8\end{array}$ & $\begin{array}{r}23,6 \\
6,2\end{array}$ \\
\hline 13181 & 9,9 & $\begin{array}{l}\% \text { fraction } \\
\% \mathrm{CaCO}_{3} \\
\text { per fraction }\end{array}$ & $\begin{array}{r}34,6 \\
1,1\end{array}$ & $\begin{array}{l}11,5 \\
17,6\end{array}$ & $\begin{array}{r}8,7 \\
16,3\end{array}$ & $\begin{array}{l}22,1 \\
12,9\end{array}$ & $\begin{array}{l}5,2 \\
9,4\end{array}$ & $\begin{array}{l}9,4 \\
8,9\end{array}$ \\
\hline
\end{tabular}

This conclusion does not hold completely for the fraction $75-1400$ micron and does not hold at all for the fraction over 1400 micron. The $\mathrm{CaCO}_{3}$-content of this fraction is rather variable, according to the presence, yes or no, of more or less shell fragments. In the Zuiderzee deposits of the Northeasternpolder this fraction consists for $60-95 \%$ of $\mathrm{CaCO}_{3}$. The lagoon sediments in the former Yssellake and the coastal deposits contain only $5-25 \% \mathrm{CaCO}_{3}$ in the fraction $>1400$ micron.

The existence of a relation between the $\mathrm{CaCO}_{3}$-content of the coarser fractions and the granulometric composition of the sample — as, perhaps, might be concluded from the data of ZuUR (1936) on the old sea clay in the Wieringermeer - could not be shown for the recent sediments in the Zuiderzee area.

From the foregoing it has to be concluded that within one region the $\mathrm{CaCO}_{3}$-content of sediments with the same clay content is governed by the frequency distribution of the other fractions. A fine example is given in FIG. 4 (Zuidersloe, compared with Braakman). Another example is to be found in the thesis of Wiggers (1955).

Finally it has to be mentioned that in the Dutch Waddenarea the material suspended in the seawater and the coastal sediment showed nearly the same distribution of $\mathrm{CaCO}_{3}$ over the various soil fractions.

\section{2.}

Along the continental coast of the Northsea the $\mathrm{CaCO}_{3}$-content of newly deposited sediments with comparable clay content decreases from the south to the north. In TABLE 3 and FIG. 3 may be seen how substantial these differences are.

The $\mathrm{CaCO}_{3}$-content of all fractions decreases from beyond Montreuil to Esbjerg, but the relations between the $\mathrm{CaCO}_{3}$-content of the various fractions prove to be rather identical, irrespective of the origin or the granulometric composition of the sample (TABLE 1).

The relative $\mathrm{CaCO}_{3}$-content of the clay fraction, indeed, seems to decrease from France to Denmark (i.e. with decreasing $\mathrm{CaCO}_{3}$-content of the sediments), but for the rest the distribution of the $\mathrm{CaCO}_{3}$ shows the same trend for all samples. 
TABLE 3. Relation between $\mathrm{CaCO}_{3}$-content and clay-content in young marine muds

\begin{tabular}{|c|c|c|}
\hline Region & Clay content & $\mathrm{CaCO}_{3}$-content \\
\hline France (Northseacoast) & 19,0 & 36,7 \\
\hline Belgium $\ldots \ldots \ldots$ & 34,2 & 24,1 \\
\hline Western Schelde (Sloe) & 30,0 & 22,2 \\
\hline Grevelingen $\ldots \ldots \ldots \ldots \ldots \ldots$ & 28,6 & 19,2 \\
\hline Waddensea & 31,5 & 14,0 \\
\hline Jadebusen $\quad \ldots \ldots \ldots \ldots \ldots \ldots \ldots$ & 28,1 & 11,7 \\
\hline Schleswig-Holstein $\ldots \ldots \ldots \ldots \ldots$ & 37,8 & 5,9 \\
\hline Denmark (S.W. Jutland) . . & 37,7 & 5,4 \\
\hline
\end{tabular}

Note

The figures for the Dutch regions are averages of many data. For the other regions, generally, only a few figures could be averaged.

FIG. 3. Relation between $\mathrm{CaCO}_{3}$-content and clay content (both in $\mathrm{g}$ per $100 \mathrm{~g}$ dry matter) in sediments from the Zuidersloe and from the Dutch Waddensea

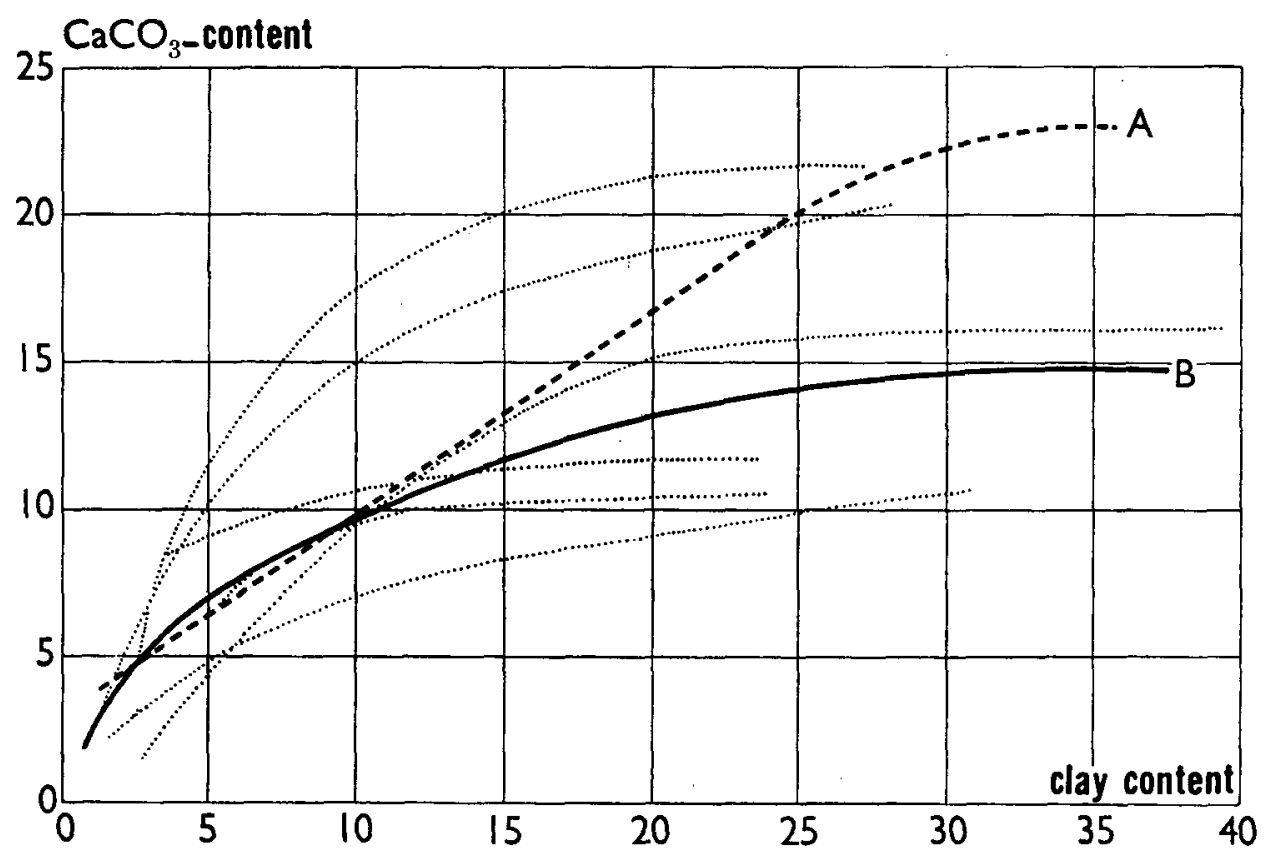

A Zuidersloe B Waddenarea

3.3.

In estuaries the $\mathrm{CaCO}_{3}$-content of the sediment also decreases with decreasing salinity of the sedimentary conditions (FIG. 4).

Notwithstanding this fact, here, in the brackish environment, too the relation between the $\mathrm{CaCO}_{3}$-content of the fractions remains about the same as under full-marine conditions (TABLE 4).

However, this does not hold for the lagoon sediments in the Yssellake which show a deviating pattern of $\mathrm{CaCO}_{3}$-fractionation. Remarkable is the even distribution; the $\mathrm{CaCO}_{3}$-content of the fractions varies only slightly (TABLE 5). 
FIG. 4. Relation between $\mathrm{CaCO}_{3}$-content and clay content (both in $\mathrm{g}$ per $100 \mathrm{~g}$ dry matter) in sediments along the Westerschelde

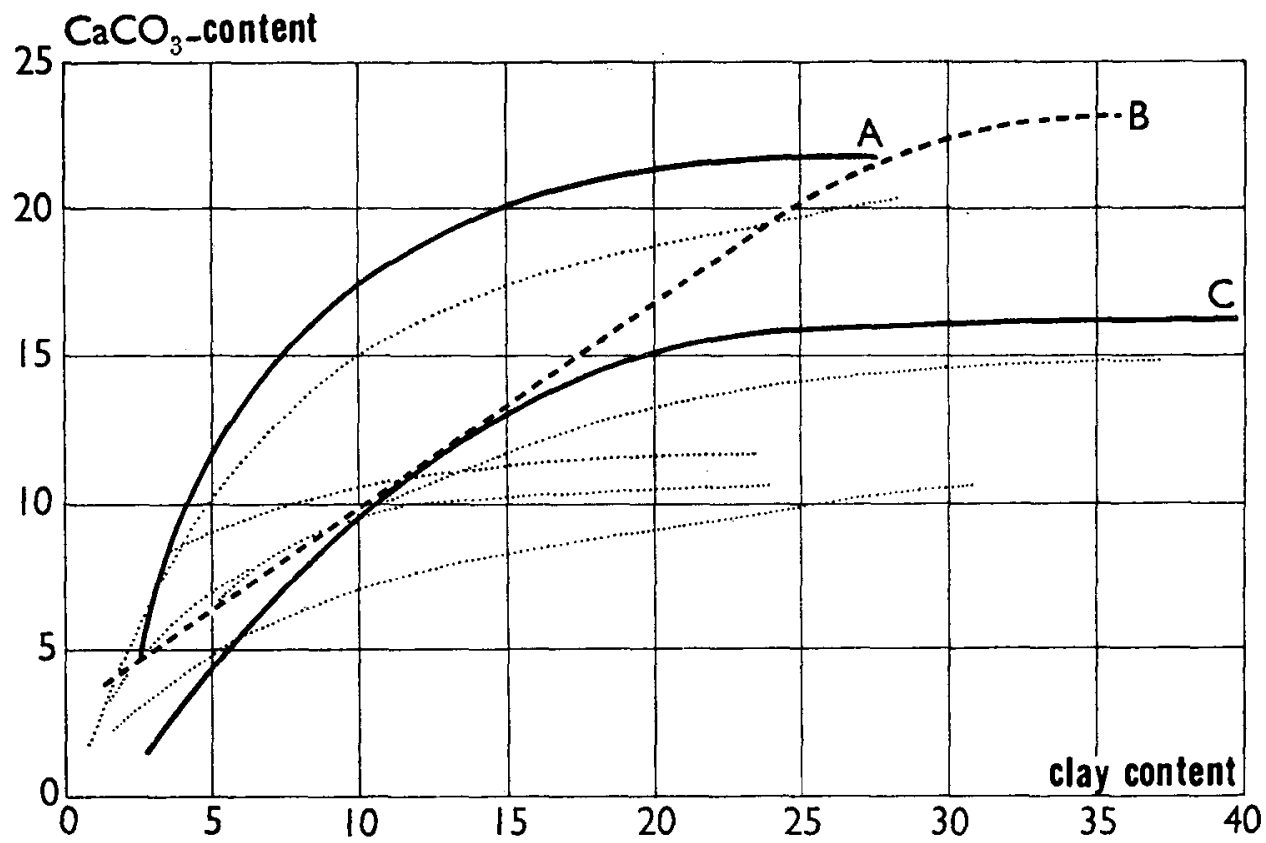
A Braakman
B Zuidersloe
C Saaftinge

TABLE 4. Relative $\mathrm{CaCO}_{3}$-percentages in fractions of slightly brackish deposits (lower Rhine near Klundert). The highest $\mathrm{CaCO}_{3}$-content is indicated as $100 \%$

\begin{tabular}{cccccccccc}
\hline $\begin{array}{c}\text { No of } \\
\text { sample }\end{array}$ & $\begin{array}{c}\text { Clay } \\
\text { content }\end{array}$ & $\begin{array}{c}\text { Total } \\
\mathrm{CaCO}_{3}\end{array}$ & \multicolumn{7}{c}{ Fraction in micron } \\
\cline { 5 - 8 } & & & $0-2$ & $2-8$ & $8-16$ & $16-35$ & $35-50$ & $50-75$ \\
28611 & 17,4 & 14,4 & 24 & 89 & 100 & 75 & 64 & 71 \\
68161 & 11,1 & 9,5 & 24 & 79 & 100 & 75 & 85 & 60 \\
\hline
\end{tabular}

TABle 5. $\mathrm{CaCO}_{3}$-percentages in fractions of Zuiderzee- and Yssellake-deposits

\begin{tabular}{lccccccrr} 
Type of sediment & \multicolumn{9}{c}{ Fraction in micron } & \multicolumn{1}{c}{ Total } \\
\cline { 2 - 7 } & $0-2$ & $2-8$ & $8-16$ & $16-35$ & $35-50$ & $50-75$ & CaCO $_{3}$ \\
in \%
\end{tabular}

It stands to reason, that for these freshwater sediments the relation between $\mathrm{CaCO}_{3}$ content and clay content is different from the relation valid for marine deposits 
(FIG. 5). In this graph not the data of the old lagoon deposits have been plotted, but figures of very recent Yssellake sediments.

Not only data regarding the size of the $\mathrm{CaCO}_{3}$-particles have been gathered, also the character of the particles and their chemical composition have been studied.

\subsection{1.}

Thus, the fractions of six samples were examined (by Dr. FAVEJEE) under the microscope. It proved that in all samples the organogenic $\mathrm{CaCO}_{3}$-particles form an

Fig. 5. Relation between $\mathrm{CaCO}_{3}$-content and clay content (both in $\mathrm{g}$ per $100 \mathrm{~g}$ dry matter) in recent Yssellake deposits

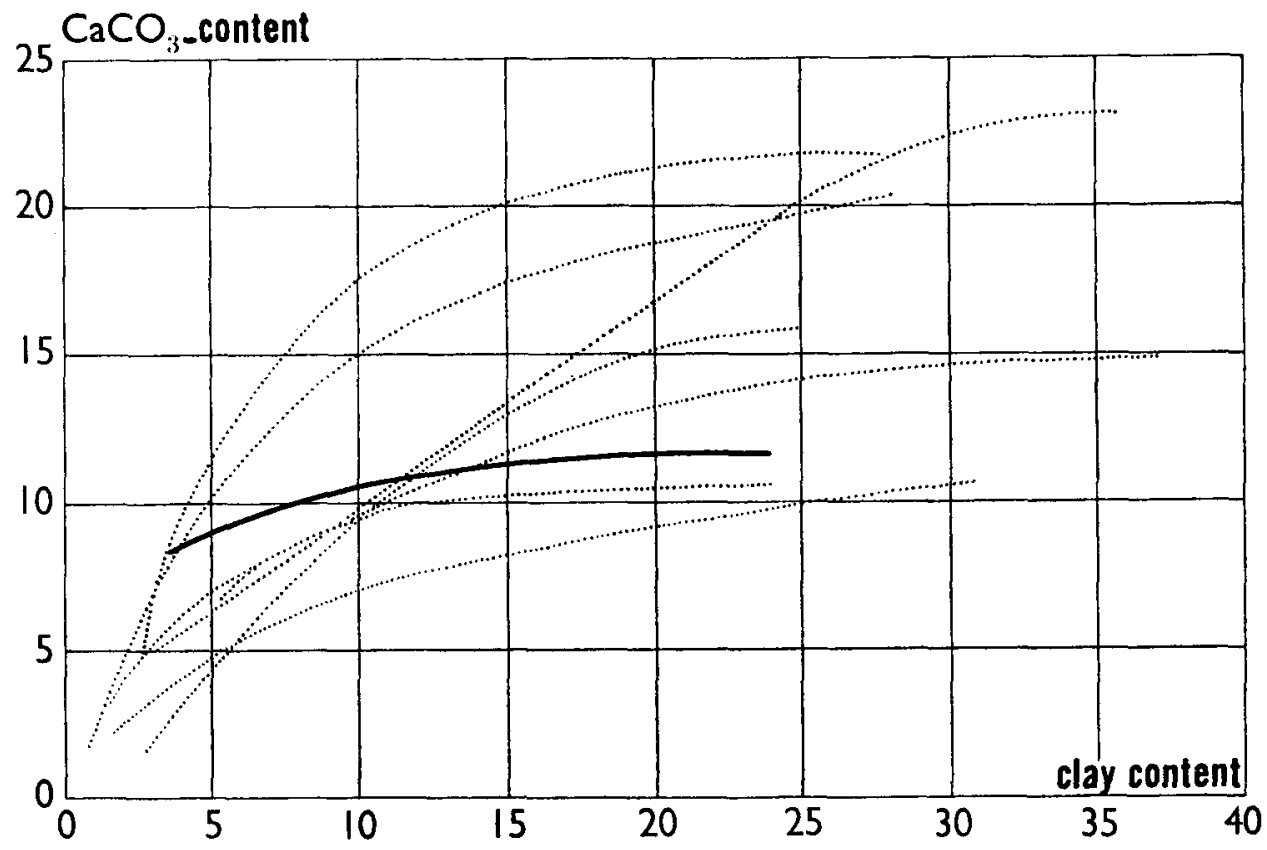

important part of the total $\mathrm{CaCO}_{3}$, often the bulk of these particles could not be determined, but fragmented shells, Foraminifera, Ostracoda and spines of Echinodermata are found and in particular in the fine fractions (below 16 micron) some rhomboedra and fine, needleshaped particles are present. The number of Foraminifera seems to decrease from south to north; in the French sample (examination by Dr. VAN VOORTHUYSEN), indeed, these Foraminifera partly are fossile (Cretaceous).

\subsection{2.}

Further $\mathrm{MgCO}_{3}$-content has been determined. Results of the various methods diverge somewhat, but, perhaps, comparison is not correct because it is not always clear as to how far the determined " $\mathrm{MgCO}_{3}$ " in fact is dolomite and which is the $\mathrm{MgCO}_{3}$ content of this dolomite. TABLE 6 provides some data, the figures have been obtained by averaging results of various methods and comparable samples. These figures do 
TABLE 6. $\mathrm{CO}_{2}$ bound to $\mathrm{Mg}$, as percentage of total carbonates

\begin{tabular}{|c|c|c|}
\hline Sampling region & $\begin{array}{l}\text { Number of } \\
\text { samples }\end{array}$ & $\begin{array}{c}\mathrm{CO}_{2} \text { bound to } \\
\mathrm{Mg} \text { in } \% \text { of } \\
\text { total } \mathrm{CO}_{2}\end{array}$ \\
\hline Harbour of Dunkirk & 1 & 5 \\
\hline Zuidsloe $\quad \ldots \ldots \ldots \ldots \ldots \ldots$ & 16 & 7 \\
\hline Zuiderzee $\quad \ldots \ldots \ldots \ldots \ldots \ldots \ldots$ & & \\
\hline Yssel delta $\ldots \ldots \ldots \ldots \ldots \ldots$ & 1 & 6 \\
\hline Lagoon deposits & 2 & 22 \\
\hline Zuiderzee deposits & 2 & 18 \\
\hline Lauwerszee $\quad \ldots \ldots \ldots \ldots \ldots \ldots$ & 1 & 10 \\
\hline Schleswig $\ldots \ldots \ldots \ldots \ldots \ldots$ & & \\
\hline Southern part. & 6 & $30^{*}$ \\
\hline Northern part. & 2 & 18 \\
\hline Holbeach marsh $\ldots \ldots \ldots \ldots \ldots$ & 1 & 27 \\
\hline
\end{tabular}

* Results of 1 method only.

not differ markedly from those of BRUIN (1938), CROMMELIN (1943) and VAN DER MAREL (1950).

Some fractions have been analysed too. However, the number of data is too small to allow established conclusions. It seems, indeed, that the highest $\mathrm{MgCO}_{3}$-contents (in relation to $\mathrm{CaCO}_{3}$ ) are found in the middle group of the analysed fractions (TABLE 7).

TABLE 7. $\mathrm{CO}_{2}$ bound to $\mathrm{Mg}$, as percentage of total carbonates in sample 68161 from Klundert (lower Rhine)

\begin{tabular}{cccccccc}
\hline $\begin{array}{c}\text { Fraction in micron } \\
\mathrm{CO}_{2} \text { bound to } \mathrm{Mg} \text { in } \%\end{array}$ & $0-2$ & $2-8$ & $8-16$ & $16-35$ & $35-50$ & $50-75$ & $>75$ \\
of total $\mathrm{CO}_{2} \cdots \cdots$ & 11 & 11 & 6 & 26 & 39 & 21 & 11 \\
\hline
\end{tabular}

\subsection{3.}

The lower $\mathrm{CaCO}_{3}$-content of brackwaterdeposits may be explained by decalcification during the sedimentation, due to a high $\mathrm{CO}_{2}$-production (BENNEMA, 1953) and/or oxidation of sulphides (VAN DER SPEK, 1952). The related experiments only showed slight indications that hampering the $\mathrm{CO}_{2}$ from escaping into the air promoted the decalcification and that, in particular in the more or less aerated samples, the addition of organic matter also increased the loss of $\mathrm{CaCO}_{3}$. But none of the differences found proved to be significant. Maybe the carrying out of the experiments was not adequate.

\section{Discussion}

4.1 .

The first point to be discussed is the origin of the $\mathrm{CaCO}_{3}$ in the relative marine sediments. In view of the data gathered, the only reasonable explanation for the wide gap in $\mathrm{CaCO}_{3}$-content between samples of the Channel coast and those of the $R \emptyset \mathrm{m} \emptyset \mathrm{dam}$ is presented by the supposition that the materials from which the sediments originate show differing $\mathrm{CaCO}_{3}$-contents. 
The various opinions (BrockmanN, 1937; Crommelin, 1943; KöpPen, 1951) with respect to the origin of the sediments will not be discussed here. Whether the sediments along the coast of Schleswig and southern Jutland come from the Northsea (WETzEL, 1931) or from reworked Waddendeposits (Ditrmer, see Verslag etc., 1952) is not important. The source for the coastal accretion will be mainly pleistocene material, as such, generally, relatively poor in $\mathrm{CaCO}_{3}$. May be this material has been enriched with $\mathrm{CaCO}_{3}$ due to fluviatile admixtures (In lectures DE GROoT communicated about transport of fluviatile material along the Northsea coast) or by a rather abundant life of $\mathrm{CaCO}_{3}$-curasses bearing beings (Goedecke, 1936, Prattue, 1931). Anyhow, the low $\mathrm{CaCO}_{3}$-contents of the Danish sediments cannot be explained by influence of acid, fresh riverwater (DE SMET, 1954), the water near the Røm $\varnothing \mathrm{dam}$ being completely marine (SANDERS en VerHOEVEN, 1956). Neither it is plausible (SverdRup, JoHNSON and Fleming, 1946) that the temperature gradient along the respective coast can cause a gradient in $\mathrm{CaCO}_{3}$-content as mentioned (compare ZONNEVELD, 1959). In many carefully taken samples the author could not detect any significant difference in $\mathrm{CaCO}_{3}$-content between summer- and wintersediments. And comparable differences found by ZoNNEveld (1960) in river sediments seem to have other causes than differences in temperature (private communication, ZoNNEVELD). Moreover marine sediments sampled along the Portugesian and Spanish coast often showed low $\mathrm{CaCO}_{3}$-contents. Along the southern stretch of the considered coastline the transport through the Channel (VAN VEEN, 1936) and erosion of the claybanks (Tesch and ReINHOLD, 1946) in the southern part of the Northsea (BAAK, 1936) call into being sediments rich in $\mathrm{CaCO}_{3}$. Arguments for these statements may be that Dr. VAN VoORTHUYSEN, examining one of the French samples, found fossile Foraminifera and moreover mentioned the fact that such Foraminifera were found northward till far in the Northsea (see also: van VoorthuYSEN, 1950). Samples from the claybanks mentioned, indeed, showed high $\mathrm{CaCO}_{3}$-contents (between 20 and $30 \%$ ). Though the main part of the $\mathrm{CaCO}_{3}$ in the coastal deposits will be brought there with the sediment (according to the size-distribution (DoEgLAs, 1950) this, probably, holds too for the coarser $\mathrm{CaCO}_{3}$-particles), it is definitely not claimed here that the origin of all the $\mathrm{CaCO}_{3}$ and of the other mineral parts is quite the same. Maybe part of the $\mathrm{CaCO}_{3}$ is mixed into the sediment during transport. And the share of this part in the total $\mathrm{CaCO}_{3}$-content may depend e.g. on living conditions for the $\mathrm{CaCO}_{3}$-producing fauna en route and the $\mathrm{CaCO}_{3}$-content of the seabottom over which the sediment is transported.

With respect to this point one can imagine that the route of transport can cause more or less local variations in the $\mathrm{CaCO}_{3}$-content of coastal sediments (SverdruP, Johnson and Fleming, 1946). Moreover sedimentation conditions may influence $\mathrm{CaCO}_{3}$-content of the deposits (shell banks). Compare in relation to these points, the deviating distribution of $\mathrm{CaCO}_{3}$-fractions in Camargue-sediments (CERIGHell et GAND, 1952).

Some other possible sources of $\mathrm{CaCO}_{3}$ have to be mentioned. In agreement with the ideas of MaschHAUPT (1948), in the Northsea (bio)-chemical precipitation cannot be of importance (this, perhaps, in contrast with tropical regions), precipitated $\mathrm{CaCO}_{3}$ being finely grained (BRUIN en TEN HAVE, 1935) and in the marine sediments under consideration fine particles of $\mathrm{CaCO}_{3}$ being scarce; moreover even in the finer fractions crystals only form a small part of the total $\mathrm{CaCO}_{3}$.

In coastal sediments of the area studied, formation of calcareous curasses and skeletons by organisms on the place of sedimentation is, in general, neither a pre- 
dominant factor, otherwise there was a fair chance that the $\mathrm{CaCO}_{3}$-content should be related with the rate of sedimentation, which is not the case. Another striking fact is the observation that in the Wadden area the suspended matter and the coastal deposits show the same content and size distribution of $\mathrm{CaCO}_{3}$. No doubt, in the ocean, where suspended matter of clastic origin hardly is present, the growth of calcareous plankton may govern the $\mathrm{CaCO}_{3}$-content of the deposits (TWENHOFEL, 1925). Moreover in rivermouths and on some tidal flats where plenty of food is available (BrockMANN, 1929), a luxurious development of small organisms (among them Foraminifera) surely may raise the $\mathrm{CaCO}_{3}$-content of the sediments (GOEDECKE, 1936; PrattJe, 1931), but obviously not so much that the relation between $\mathrm{CaCO}_{3}$ content of the sediments and their geographical position (or better said their origin) is completely disturbed.

4.2 .

The explanation of the size distribution of the $\mathrm{CaCO}_{3}$ is more or less related to that of the origin of the $\mathrm{CaCO}_{3}$. Maybe that the deposits from which the sediments originate show already a comparable fractionation of the $\mathrm{CaCO}_{3}$, but even in that case it has to be explained why in these deposits the $\mathrm{CaCO}_{3}$ is distributed in this way. From the data (size distribution of the $\mathrm{CaCO}_{3}$, microscopical observation of $\mathrm{CaCO}_{3}$-particles, $\mathrm{CaCO}_{3} / \mathrm{MgCO}_{3}$ relation in the fractions studied) it may be supposed that the greater part of the $\mathrm{CaCO}_{3}$ comes into the sediment in a rather large form (varying between complete shells with a length of several $\mathrm{cm}$ and Foraminifera with a size of e.g. half of a millimeter). MaschHaupT's (1950) supposition that precipitation of $\mathrm{CaCO}_{3}$ must occur because in all sediments $\mathrm{MgCO}_{3}$ is found too, does not hold. Shells, indeed, according to MaschHaupT (1948) as well as to own analyses only contain slight quantities of $\mathrm{MgCO}_{3}$. In samples of Cardium edule from Denmark, the Wadden area and the Delta region hardly any $\mathrm{MgCO}_{3}$ could be demonstrated. But the $\mathrm{MgCO}_{3}$ may originate from other marine beings than shells (TWENHofEL, 1925).

It might be supposed from TABLE 7 that in the coarser fractions the shell fragments are somewhat more important whereas the relatively low $\mathrm{MgCO}_{3}$-figures of the finest fractions might point to a slower disintegration of $\mathrm{MgCO}_{3}-$ (or $\mathrm{MgCO}_{3} . \mathrm{CaCO}_{3}$ ) compounds. During transport disintegration of the $\mathrm{CaCO}_{3}$-particles occurs and hence there is a steady supply of $\mathrm{CaCO}_{3}$ from the coarser fractions to the finer ones.

The level of $\mathrm{CaCO}_{3}$ in each fraction is depending upon this supply and upon the removal of $\mathrm{CaCO}_{3}$ to a finer fraction. The rate of supply and removal probably depending on the quantity of $\mathrm{CaCO}_{3}$ present and upon the rate of weathering, the latter (under comparable conditions) for each fraction probably also being governed mainly by this very level of $\mathrm{CaCO}_{3}$ in the relative fraction. This makes for the similarity in the relation between the $\mathrm{CaCO}_{3}$-percentages of the various fractions, irrespective of the clay content and the origin of the samples. As the fractions become finer, disintegration goes relatively slower (GALLOWAY (1922), as quoted by Twenhofel, 1925) and a higher $\mathrm{CaCO}_{3}$-content is required to keep supply and removal in equilibrium. Hence a gradual increase in $\mathrm{CaCO}_{3}$-content from coarser to finer fractions is observed.

The finer fractions (below \pm 25 micron (FAVEJEE, 1951)) are flocculated (even in brackish deposits (BourcarT, 1939)) and the $\mathrm{CaCO}_{3}$ which comes into these fractions probably is protected against further disintegration, this may explain why the finest $\mathrm{CaCO}_{3}$-particles are scarce (TABLE 1). In the Almere-sediments, which have been 
deposited in a peptised state, this protection against weathering failed and here the clay fraction shows the same $\mathrm{CaCO}_{3}$-content as the other fractions and moreover the maximum in 2-16 micron fractions disappeared (TABLE 5).

Maybe that the French samples contain some more $\mathrm{CaCO}_{3}$-particles below 2 micron (TABLE 1), because this material has been formed (at least partly) by erosion of the limestone rocks.

\section{3.}

The author has no unassailable explanation for the comparably low $\mathrm{CaCO}_{3}$-content of brackwaterdeposits in river mouths. Perhaps the causes vary from case to case and maybe that even in one and the same estuary various processes prove to occur (ZoBELL, 1946). During sedimentation decalcification caused by abundant production of $\mathrm{CO}_{2}$ (decay of organic matter) or by oxidation of sulfides is, perhaps, not negligible. Probably a luxuriant microbial life in the brackish region - mentioned by many authors (GoEDECKe, 1936; BRoCKMANN, 1929) and perhaps testified by the high fosfate- and organic-matter contents of these brackwatersediments - withdraws an appreciable quantity of $\mathrm{CaCO}_{3}$. The $\mathrm{Ca}$ may be found back in various organic or organogenic compounds and, perhaps, just outside the estuaries (Prattue, 1931). In some cases the acidity of the riverwater may cause a lowering of the $\mathrm{CaCO}_{3}$ content of the sediments; the whole $\mathrm{CaCO}_{3}$-regime shows a close correlation with the salinity of the environment (KüHL und MANN, 1953); maybe that some estuarine deposits are mixtures of marine and fluviatile sediments, the latter sometimes being less rich in $\mathrm{CaCO}_{3}$.

Except, possibly, in the last case one should always expect a decrease of the $\mathrm{CaCO}_{3-}$ content of the finest fractions, unless the disintegration of the $\mathrm{CaCO}_{3}$-particles should proceed fastly. This, anyhow, may be shown in TABLE 8 , which is based on the assumptions that in the brackwatersediments of the lower Rhine the coarsest fraction shows no loss of $\mathrm{CaCO}_{3}$ and that the original $\mathrm{CaCO}_{3}$-contents of the fractions had the same frequency distribution as the Zuidersloe-sediment. It is obvious that the $0-2$ micron and - even more - the 2-8 micron fraction lost a considerable part of their $\mathrm{CaCO}_{3}$, this in contrast with the coarser fractions.

TABLE 8. Relative $\mathrm{CaCO}_{3}$-percentages in fractions of comparable full-marine and brackish sediments

\begin{tabular}{cccccccc}
\hline Type of sediment & \multicolumn{7}{c}{ Fraction in micron } \\
\cline { 2 - 7 } & $0-2$ & $2-8$ & $8-16$ & $16-35$ & $35-50$ & $50-75$ \\
Zuidsloe $\ldots \ldots \ldots \ldots \ldots \ldots$ & 25 & 100 & 83 & 61 & 57 & 56 \\
Lower Rhine $\ldots \ldots \ldots \ldots \ldots$ & 20 & 71 & 85 & 64 & 64 & $56^{*}$ \\
\hline
\end{tabular}

* This figure has been made equal to that of the Zuidsloe.

\section{ACKNOWLEDGEMENT}

It happened that this study took several years and in course of time many colleagues helped in gathering samples, furnishing data etc. The author is indebted to Messrs. Prof. Dr. N. Nielsen, N. Kingo Jakobsen, B. Jakobsen, K. Rasmussen, Dr. E. Wohlenberg, Dr. D. König, the late Prof. Dr. G. Deloffre, Dr. J. H. van VoorthuYsen, Dr. A. De Groot, Ir. Ferguson and in particular Dr. Favejee with whom the author had several discussions and Ir. J. C. DE KoNING, who, in the first years of the study, collected and examined many data. 
BAAK, J. A.

Beeftink, W. G.

Bennema, J.

BeverwiJk, A.

BOURCART, J.

BrockmanN, C.

Bruin, P.

en J. TEN Have

Cerighelli, P., et E. Gand Crommelin, R. D.

Dechering, F. J. A.

Dogglas, D. J.

Favejee, J. Ch. L.

GoEDECKE, E.

HoFstee, J.

Hooghoudt, S. B.

KÖPPEN, R.

Marel, H. W. van der

Maschhaupt, J. G.

\section{LITER A TURE}

1936 Regional petrology of the southern North sea. Thesis, Wageningen.

1962 The vegetation of the saltmarshes in the deltaic area of the Netherlands, its environment and its place in the system of the West-European saltmarshes communities. Thesis, Wageningen (Not yet published).

1953 De ontkalking tijdens de opslibbing bij Nederlandse alluviale gronden. Boor en Spade. d1. 6, 30-41.

1958 Onderzoek naar de mogelijkheid om het calcium- en magnesiumcarbonaat in de grond te bepalen met zoutzuur en azijnzuur als oplosmiddelen. Intern rapport afd. Onderz. Directie Wieringermeer (Noordoostpolderwerken).

1939 Sur les vasières des estuaires de la Manche. C.R. Séanc. Geol. France. 6, 73-74.

1929 Das Brackwasser der Flussmündungen als Heimat und vernichter des Lebens. Natur und Museum. 59, 401-414.

1937 Küstennahe und Küstenferne Sedimente in der Nordsee. $A b h$. Naturwiss. Ver. Bremen. 30, 78-89.

1938 De anwezigheid van calciummagnesiumcarbonaat naast calciumcarbonaat in kleigronden en de ontleding dezer carbonaten onder invloed van zoutzuur, azijnzuur en de bodemzuren. 's-Gravenhage, 1938. Versl. Landbouwk. Onderz. No. 44, p. $693-739$.

1935 Het bepalen van magnesiumcarbonaat naast calciumcarbonaat in grond. Chem. weekbl. 32, 375-378.

Les sols de Camargue. Ann. Agron. 6, 863-938.

1943 De herkomst van het Waddenslib met korrelgrootte boven 10 micron. Verh. Geol, mijnbouwk. genootsch., geol. serie 13, $299-333$.

1942 Rapport betreffende het onderzoek naar de mogelijkheid van inpoldering van de schorren bij Ossendrecht (N.Br.). Groningen.

1950 De interpretatie van korrelgrootte analysen. Verh. geol. mijnbouwk. genootsch. 15, 247-257.

1951 The origin of the "Wadden" mud. Meded. Landbouwh.school Wageningen. 51, 113-141.

1936 Kalkgehalt im Oberflachenwasser der Unterelbe. Arch. der deutschen Seewarte. 55, 1-37.

1955 Onderzoek naar de mogelijkheden om de som van de componenten bij de granulometrische samenstelling in grond dichter bij de theoretische waarde te brengen. Intern rapport afd. Onderz. Directie Wieringermeer (Noordoostpolderwerken).

1957 Analysemethoden voor grond, gewas, water en bodemvocht. Uitg. Directie Wieringermeer (Noordoostpolderwerken).

1945 Een gecombineerde zeef- en pipetmethode voor de bepaling van de granulaire samenstelling van gronden. Versl. Landbouwk. Onderz. No. 20.50. (13) A.

1951 Der Schlick im Küstengebiet der Nordsee. Die Umschau. 91, $389-390$.

1950 Het voorkomen van calciet en dolomiet in de kleifractie van de Nederlandse gronden. Landbouwk. Tijdschr. 62, 300-306.

1948a Bodemkundige onderzoekingen in het Dollardgebied. 's-Gravenhage, 1948. Versl. Landbouwk. Onderz. No. 54.4. 
Maschiaupt, J. G.

PrattJe, O.

SANDERs, P., en

B. VERHOEVEN

SKINNER, S. I. M.,

R. L. Halstead and

J. E. BRYDON

SMET, L. A. H. DE

SPEK, J. VAN DER

SVERDRUP, H. U.,

M. W. JOHNSON and

R. H. Fleming

Tesch, P., en

T. REINHOLD

Trilling, F.

Twenhofel, W. H. F.

VEEN, J. VAN

Verslag

VOORTHUYSEN, J. H. VAN

Wetzel, W.

Zobell, C. E.

ZONNEVELD, I. S.

ZUUR, A. J. 1948b De cultuurgronden op IJsselmonde. 's-Gravenhage, 1948. Versl. Landbouwk. Onderz. No. 39.

1950 Het koolzure kalkgehalte der Dollardgronden. Tijdschr. Kon. Ned. aardrijksk. genootsch. dl. 67, 114-121.

1931 Die Sedimente der deutschen Bucht. Wissensch. Meeresuntersuchungen. Neue Folge, Bd. 58, No. 6.

1956 Verslag over een reis ter bestudering van de landaanwinning in West-Duitsland en Jutland. Baflo enz. 1956. Commissie Onderz. Landaanwinning T.N.O.

1959 Quantitative manometric determination of calcite and dolomite in soils and limestones. Canadian J. Soil Sci. 39, 197205.

1954 Enkele opmerkingen over kalkarme zeekleiafzettingen. Boor en Spade. dl. 7, 169-174.

1952 Over het verdwijnen van koolzure kalk uit zeekleiafzettingen ten gevolge van de oxydatie van hierin aanwezige sulfiden. Landbouwk. Tijdschr. 64, 473--478.

1946 The oceans, their physics, chemistry and general biology. New York.

1946 De bodem van het zuidelijk uiteinde der Noordzee. Tijdschr. Kon. Ned. aardrijksk. genootsch. d1. 63, 72-84.

1928 Die Kalkfrage in den Nordseemarschen. Landwirtsch. Jahrb. $67,547-588$.

1926 Treatise on sedimentation. London.

1936 Onderzoekingen in de Hoofden in verband met de gesteldheid der Nederlandsche kust. Thesis, Delft.

1952 Verslag van een studiereis naar de landaanwinningswerken langs de westkust van Sleeswijk-Holstein en Jutland. Kampen, enz., 1952. Commissie Onderz. Landaanwinning T.N.O.

1950 Recent indigenous and uppercretaceous derived foraminifera of The Netherlands tidal flats (Wadden). Tijdschr. Kon. Ned. aardrijksk. genootsch. d1. 67, 89-94.

1930 Beiträge zur Sedimentpetrographie des Nordseebodens ins besondere des Schleswig-Holstein Wattenmeeres. Wissensch. Meeresuntersuchungen. Bd. 30.

1946 Marine microbiology. Waltham, Mass. U.S.A.

1959 Opmerkingen naar aanleiding van een excursie naar SleeswijkHolstein en Jutland, georganiseerd door de Internationale vereniging voor vegetatiekunde (juli 1956). Boor en Spade. dl. 10, 116-128.

1960 De Brabantse Biesbosch. Wageningen, 1960. Meded. Stichting voor Bodemkartering, Bodemk. studies No. 4.

1936 Over de bodemkundige gesteldheid van de Wieringermeer. 's-Gravenhage. 